\section{No viral disease after} xenotransplantation

Sir - You refer in your Briefing on xenotransplantation (Nature 391, 320-325; 1998) to a study on seroreactivity to porcine viruses in the ten diabetic patients transplanted with fetal pig islets in Stockholm, Sweden, between 1990 and 1993. The study was presented at the Xenotransplantation Congress in Nantes, France, last September.

Your description of the serological findings is correct: a number of patients tested positive for antibodies to various pig viruses. The sera have subsequently been evaluated for possible cross-reactivity with antibodies to human pathogens, and most reactivities have now been accounted for by such cross-reactivity. There remains a weak reactivity against porcine parvovirus in samples from three patients, and these are being reanalysed at the Centers for Disease Control in Atlanta, Georgia.

The statement that one patient is ill with porcine parvovirus infection is, however, false. None of the patients developed any infectious symptoms related to the xenotransplantation. Nor has any of them developed any unusual symptoms of diseases since exposure to the porcine islets. The alleged transmission of viral disease from pig to man has raised considerable concern. There has, however, been no evidence of such disease in our patients. A. Tibell

\section{G. Groth}

Department of Transplantation Surgery, Huddinge Hospital, S-141 86 Stockholm, Sweden

\section{Student cheats}

Sir - You report that incidents of cheating by students have increased significantly over three decades, amounting to more than two-thirds (73\%) of all students polled in US universities without an 'honour code' and about a half (49\%) in universities with an 'honour code' and punishments for its violation (Nature 390, 430; 1997).

At the beginning of this century, the record may have been even higher. Abram F. Ioffe (a solid-state physicist) reported in his book Meetings with Physicists (Nauka, 1983) that this problem was raised long ago by another prominent scientist, Gilbert N. Lewis (acids-bases theory), with whom he had worked at the University of California at Berkeley in the 1920s. At that time, students forced the university senate to allow them to take written examinations in the absence of instructors.

Lewis proved that $90 \%$ of the examination papers were written using unsanctioned sources. There was also an 'honour' angle. After Lewis's report, the senate ordered the students to add at the end of their work a declaration that they deserved to be trusted in examinations on their honour as American citizens. Lewis proved that this addition did not make a significant difference. (No punishment was incurred with this declaration.)

The senate was furious - with Lewis. It is tempting to suggest that the $90 \%$ rate of student cheating found by Lewis is a potential rate achieved under pure experimental conditions (in the absence of instructors and punishments), which can be reduced by instructor presence (to 73\%) and further reduced by the application of punishment (to $49 \%$ ).

Ioffe remarked that, on balance, when he examined his students orally after his course, he had only positive impressions. Thus the inclination to cheat did not seem to interfere significantly with the willingness and ability to learn.

Alexander Vinogradov

Institute of Cytology,

Russian Academy of Sciences,

Tikhoretsky Ave 4,

St Petersburg 194064, Russia

e-mail:aevin@mail.cytspb.rssi.ru

\section{Speculation is premature}

Sir - Further to your News item about a report being prepared by the National Bioethics Advisory Commission on research involving human biological materials, which prompted some correspondence (Nature 391, 314 \& 392, 14; 1998), I should like to emphasize that the commissioners are still discussing this issue and have neither reached conclusions nor made recommendations.

What do exist are working drafts prepared by staff, papers commissioned by various experts and testimony by the public and professional groups. Speculation about "likely" recommendations is therefore premature.

The commission expects to receive another staff draft in time for its next meeting on 19-20 May in Cleveland, Ohio. We intend to make this draft available to the public on our Web site

(http://www.bioethics.gov) before the meeting. The commission is planning to complete and distribute an interim report in the early spring. By distributing these documents widely, the commission hopes to benefit from public and professional comment before issuing a final report.

Eric M. Meslin

(Executive Director)

National Bioethics Advisory Commission,

6100 Executive Boulevard, Suite 5B01,

Rockville, Maryland 20892-7508, USA
Plight of hawksbill turtles

Sir - In reply to my Commentary ${ }^{1}$ on the need for open science as the basis for decisions on conservation, Anne Meylan ${ }^{2}$ muddles up several different issues about hawksbill turtles, the International Union for the Conservation of Nature (IUCN) and Cuba.

One issue is that it is now close to 18 months since the hawksbill was listed as critically endangered, but documentation has still not been provided. Meylan indicates that because those making the recommendation were specialists there is no need to question it. This appeal to authority, combined with the excuse that her working group are volunteers, will do little to increase confidence that IUCN is achieving the transparency and professionalism that is meant to underlie its categorizations of the status of species. Sanctioning publication of conclusions so far in advance of the supporting analyses is not a standard scientific practice. Meylan claims that data are already available, especially in the Groombridge and Luxmoore report ${ }^{3}$. She fails to mention that those authors suggested that the hawksbill's status could be "indeterminate" rather than "endangered".

A different issue is whether trade in wildlife can be beneficial sometimes. In the case of hawksbills, no fewer will be killed as a result of decisions made at the Convention on International Trade in Endangered Species (CITES) because the Cubans are already taking hawksbills for meat. What the CITES decision means is that the shells from turtles that are already being killed to feed impoverished people will go largely to waste instead of generating support for improved enforcement, monitoring, research, and reduction of incidental catch.

If limited trade is sanctioned under CITES, it actually provides more leverage because it is accompanied by international scrutiny through inspections and reports. Outside CITES, Cuba can do what it wishes with turtles in its waters. The possibility of regulated trade under CITES has already stimulated Cuba to devise an enforcement tool that sets new standards: every piece of hawksbill shell in the Cuban stockpile was videoed and numbered.

\section{N. Mrosovsky}

Department of Zoology,

University of Toronto,

Toronto, Ontario, M5S 3G5, Canada

e-mail:nm236@hermes.cam.ac.uk

1. Mrosovsky, N. Nature 389, 436 (1997).

2. Meylan, A. Nature 391, 117 (1998).

3. Groombridge, B. \& Luxmoore, R. The Green Turtle and Hawksbill (Reptilia: Cheloniidae): World Status, Exploitation and Trade (Secretariat of CITES, Lausanne, Switzerland, 1989). 